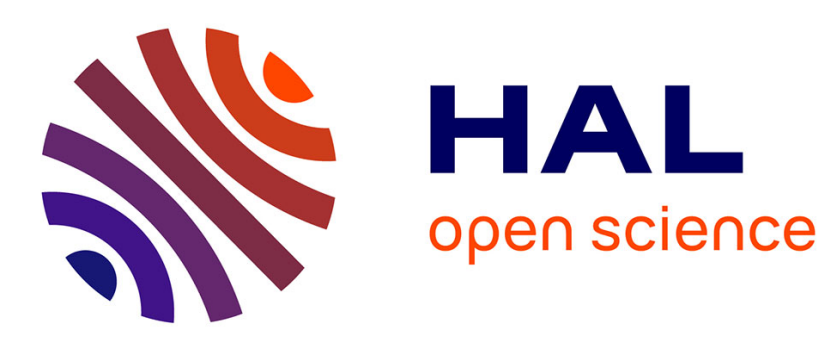

\title{
Paradigm Shift of Indian Cash-Based Economy to Cash-Less Economy: A Study on Allahabad City
}

\author{
G. P. Sahu, Naveen Kumar Singh
}

\section{To cite this version:}

G. P. Sahu, Naveen Kumar Singh. Paradigm Shift of Indian Cash-Based Economy to Cash-Less Economy: A Study on Allahabad City. 16th Conference on e-Business, e-Services and e-Society (I3E), Nov 2017, Delhi, India. pp.453-461, 10.1007/978-3-319-68557-1_40 . hal-01768539

\section{HAL Id: hal-01768539 \\ https://hal.inria.fr/hal-01768539}

Submitted on 17 Apr 2018

HAL is a multi-disciplinary open access archive for the deposit and dissemination of scientific research documents, whether they are published or not. The documents may come from teaching and research institutions in France or abroad, or from public or private research centers.
L'archive ouverte pluridisciplinaire HAL, est destinée au dépôt et à la diffusion de documents scientifiques de niveau recherche, publiés ou non, émanant des établissements d'enseignement et de recherche français ou étrangers, des laboratoires publics ou privés. 


\title{
PARADIGM SHIFT OF INDIAN CASH-BASED ECONOMY TO CASH-LESS ECONOMY: A STUDY ON ALLAHABAD CITY
}

\author{
G. P. Sahu ${ }^{1}$, Naveen Kumar Singh ${ }^{2}$ \\ Motilal Nehru National Institute of Technology Allahabad, India \\ gsahu@mnnit.ac.in
}

\begin{abstract}
This paper is an attempt to study the important factors responsible for successful implementation of digital payment (e-Payment) system in India. Examine the status of e-Payment at Allahabad city (Uttar Pradesh, Indian) and to conduct an analysis of imitation of e-Payment in other regions of India. A qualitative study with extensive literature review, interview and expert opinion was adopted to conduct the study. To analyse the result and to identify the success factor NVivo 11 Pro software is used. With the help of software 13 success factors identify namely: Anonymity, Bank Involvement, Drawer, Infrastructure, Mobility, Parties, Popularity, Range of Payment, Risk, Security, Transfer limit, Transfer mode, and Transfer time for successful implementation of digital payment at Allahabad city. The outcome will be helpful for implementation of digital payment in various other cities of India.
\end{abstract}

Keywords: digital payment, NVivo 11 Pro, cashless economy, cashbased economy, demonetisation.

\section{INTRODUCTION}

Government of India declared demonetisation as a "Shock Therapy" on 8th November 2016. Government ceased the legal tender of 500 and 1000 currency notes and launched new 2000 and 500 rupee notes in circulation. With this step of demonetization, India lost 86 per cent of its monetary base [15]. The total value of old currency notes of Rs. 500 and Rs. 1000 in the circulation is to the tune of Rs. 14.2 trillion, which is about 85 per cent of total value of circulated currency in the country [11]. After demonetization the currency now pass through the formal banking channel to get legality. From the market perspective this is a welcome move by the Indian government. Government of India tackled issues which affected the economy like, parallel economy, tax evasion, counterfeit currency in circulation and terror financing [15].

adfa, p. 1, 2011.

(c) Springer-Verlag Berlin Heidelberg 2011 
The outlook for cashless economy appears highly controversial and unsettled in India. E-payment defines as, any exchange of funds initiated via an electronic communication channel [26] or a payment made through electronic signals linked directly to deposit or credit accounts [9]. E-payment represents any kind of non-cash payment that does not involve a paper cheque [14]. A cashless economy is one in which currency notes are not used as a medium of transaction [19]. It is a hypothetical stage or situation in favour of alternative means of exchange. All the transactions are done through cards, wallets, or digital medium with minimal physical circulation of currency. In other terms, cashless economy can be defined as a situation in which the flow of cash within the economy become zero and all the transactions must be through electronic means like, credit cards, debit cards, money wallets, IMPS, RTGS, NEFT etc.

"Non-cash payments are not accomplished merely by exchanging the payment instrument between payer and payee, but transferring deposit money between the payer's bank and the payee's bank. Non-cash payment instruments provide the mechanism for this bank-to-bank transfer. Non-cash payment instruments, such as cheques, NEFT, RTGS, must specify the payment amount, the names of the payer and the payee and their banks."

- World Bank

The primary objective of this study is to identify factors influencing successful implementation of digital payment in India. An extensive literature review, interview and expert opinion have been conducted to identify the success factors of digital payment. Using NVivo 11 Pro software 13 success factors were recognized and validated namely: Anonymity, Bank Involvement, Drawer, Infrastructure, Mobility, Parties, Popularity, Range of Payment, Risk, Security, Transfer limit, Transfer mode, and Transfer time. This study will helpful in implementation of digital payment in other region of India. As well as this will help the researches to their studies on digital payment.

\subsection{The payment environment - an overview}

A report of The Boston Consulting Group [25] estimates that, consumer are 90 percent likely to use digital payments for offline and online transactions, and around 60 percent of the total value of such payments will come from offline merchants such as unorganised retailers, fast food corners and 
transport. Moving against backdrop of, overflow of currency, and black money in the country; the adoption of electronic payment channels that include cards, ATMs, POS terminals, mobile phones and Internet flow the secure, convenient and cheapest transactions that are not only provide the transparency but also provide the easy way for global transaction. Payment system is one of the substantial changes policies in all over the world. Initially, trading through barter system was common, a system where people exchange their livestock from food, crop or goods [1]. But the present concept of cashless economy is completely different; here the cashless transactions are made through digital currencies. Cashless banking strengthens monetary policy effectiveness and that the current level of e-money usage does not pose an intimidation to the stability of the financial system [21].

Cashless Transactions system was introduced in the 1950s and now become the essential form of "ready money", which reduces the risk of cash handling, theft by pickpocket etc. During 1990's, the growing popularity of ebanking made the use of cashless transactions popular among the technologically advanced countries. In 2010 the digital payment methods became well established in most of the countries across the world. Internet banking is eminent example of IT in the service industry; it is convenient and time saving in comparison to traditional banking [30]. Earlier, online tools like Paypal, NFC payments by smartphone or electronic cards, digital wallet system operated by Apple, electronic banking and bill payment system helped the users towards cashless transactions online. There were different types of payment systems exist before the emergence of modern banking system in India [25]. Banking operations was done through manually, which lead to slow transactions. This system involves "Book-Keeping", ie, posting of transactions from one ledger to another ledger manually without using any machine. Computer and electronic machines was used for figure or counting of money. It takes a lot of time and effort to do manually work. Banks having more than one computer are like "triton among the minnows" and that single computer helps to improve the crawling working condition. A local study [4] mentioned that, "Payment through cash is an expensive proposition for government". There are many factors which influence users to adopt technology [5], and two factors are important in these factor. First, "utility", in which people are likely to use or not use an application to the extent they believe it will help them to perform their job better. Second, "convenient", in which people 
perceive that if the technology is too hard to use, they likely not to adopt and not to use it even though they believe that the technology is useful.

\section{Advantages of a Cashless Economy}

The foremost advantage of having no cash is to reduce the use of paper, cost, elimination of carrying and managing problem etc. A Study by Hirschman [13] used focus groups to identify 11 payment characteristics salient to the preference and usage of payment instruments. Such included budgeting, control of spending, documentation, reversibility, transaction record, acceptability, leverage potential, transaction time, security, social desirability/prestige, and transfer time. Central bank in the Netherlands identified four overarching payment system characteristics: safety (financial risk by using digital instrument), speed (time needed to complete the transaction), costs (that the consumer carries for the possession and actual use of a payment instrument), and ease of use (effort of consumer to complete the payment process with a electronic medium).

\section{Challenges of Cashless Economy}

Every reforms has some pros and cons, hence, there are few challenges to proposed cashless economy. Study [40] suggested that there are basic ICT literacy is necessary to enjoy the benefits of e-payment but cash and cheques will remain popular because consumers are not convinced of the benefits of using e-payment [12]. Prior adoption of IT had an identifiable impact because customers will usually adopt a new service only when they have similar experiences before [6]. A very high and unbreakable security system needed to secure the transactions from hackers and cyber criminals [3][7-8][16][18][22-24][29][31-33][35][38]. The central bank of Malaysia [20] cites lack of awareness as one of the reasons why consumers are not using epayment. Cashless economy won't be readily popular among the region where the people not much literate or aware.

However, till FY 2016-17, Indian government introduced lots of methods to digital payment like, Banking Cards (Debit/Credit/Cash/Travel/Other); Unstructured Supplementary Service Data (USSD); Aadhaar Enabled Payment System (AEPS); Unified Payments Interface (UPI); Mobile Wallet; Banks PrePaid Cards; Point of Sale (PoS); Internet Banking including, National Electron- 
ic Fund Transfer (NEFT), Real Time Gross Settlement (RTGS), Electronic Clearing System (ECS), Immediate Payment Service (IMPS); Mobile Banking; Micro ATMs. Very few literatures are available on factors affecting successful implementation and functionality of digital payment in India. This paper is an attempt to fill this gap with reference to Allahabad city and to conduct a feasibility analysis of imitation of digital payment on other cities and rural areas of India.

\section{RESEARCH METHODOLOGY}

To conduct the study a qualitative approach with in-depth literature review followed by interview and expert opinion through which comments/perceptions were recorded. The collected data were analyzed by using NVivo 11 Pro software (a qualitative software), which helps to provide systematize and order data with visual result. Nvivo facilitate careful and faithful qualitative research analysis [2] [10]. NVivo is Qualitative Data Analysis (QDA) application software developed by QSR International. NVivo not only help the researcher to managing and categorization of data according to the need and requirement of the researcher, but also it is convenient, efficient, effective and more user friendly in comparison to manual task for qualitative research [27]. NVivo 11 helps the researcher to visualise the result through cloud analysis, word tree map, node analysis etc. For primary data, vendors from Allahabad city and experts from Motilal Nehru National Institute of Technology (MNNIT) Allahabad has been interviewed and recorded for analysis using transcript command. On the other hand various journal, magazine, internet, newspaper etc. has been reviewed to collect secondary data. Afterwards, with the help of coding process, both primary and secondary data imported to the NVivo 11 Pro software. With the help of coding process 13 success factors were analysed namely: Anonymity, Bank Involvement, Drawer, Infrastructure, Mobility, Parties, Popularity, Range of Payment, Risk, Security, Transfer limit, Transfer mode, and Transfer time for successful implementation of digital payment in India.

\section{Case Study of Allahabad City}

Allahabad is one of the member districts of "KAVAL towns" which are also known as "Panchpuri Nagar" (five biggest cities) of Uttar Pradesh. KAVAL 
towns include; Kanpur, Agra, Varanasi, Allahabad, and Lucknow. According to census 2011, the population of Allahabad is 5,954,391 which is highest population [42] out of total 71 districts of Uttar Pradesh. It is situated at the confluence (Sangam) of three rivers Ganga, Yamuna and the mythological Saraswati. Allahabad is known for academic ambience and presently houses six national level Institutes /Universities. The literacy rate of Allahabad [42] is $72.32 \%$ which slightly lower than the literacy rate of India ie. $74 \%$. There are 125 bank branches (commercial \& cooperative) and around 181 ATMs in Allahabad city. By interview of respondents it is observed that, shopkeepers are using cash as well as digital equipments for transaction. Some shopkeepers are using electronic devices/digital equipments from long time, while some have started after demonetisation. Paytm, internet banking, card swipe machine etc. are the medium of digital transaction. Customers are also demand and encourage digital medium of transaction. However, they face various problems like, internet connectivity, lack of trust in online services, threat of online theft etc.

\section{ANALYSIS AND INTERPRETATION}

Coding involves collecting all the material about a particular study in a node for further exploration. In this study the coding was carried out in 2 phases: first, Video and Audio recorded during the interview of expert and respondent, and second, literature review available as a secondary source of data. Coding process includes analyse of data with the help of "count" and "frequency of occurrence" of word from the data collected from primary and secondary source.

\section{Number and Frequency Table}

Following table shows the word frequency of occurrence under the different factors during the interview as well as in the literature review of the study

Table 1. Number of world count and frequency

\begin{tabular}{|l|c|r|}
\hline \multicolumn{1}{|c|}{ Factors } & Count & Weighted \% \\
\hline Anonymity & 115 & 4.92 \\
\hline Bank Involvement & 58 & 2.48 \\
\hline Drawer & 33 & 1.41 \\
\hline
\end{tabular}




\begin{tabular}{|l|c|r|}
\hline Infrastructure & 572 & 24.48 \\
\hline Mobility & 154 & 6.59 \\
\hline Parties & 56 & 2.39 \\
\hline Popularity & 176 & 7.53 \\
\hline Range of Payment & 65 & 2.78 \\
\hline Risk & 271 & 11.6 \\
\hline Security & 260 & 11.13 \\
\hline Transfer limit & 57 & 2.44 \\
\hline Transfer mode & 449 & 19.26 \\
\hline Transfer time & 70 & 2.99 \\
\hline
\end{tabular}

From table 1, it is evident that the factor like Infrastructure, transfer mode, risk and security are used maximum times and most commonly, whereas factors like drawer, parties, transfer limit, and bank involvement are used minimum and less commonly by the respondents.

It may therefore be said that infrastructure is most concern part of digitalisation including, transfer mode, risk, and security. So the government need to more focus on the infrastructure of the system which includes, internet connectivity, methods of payment, availability of internet enabled phones, awareness and ICT literacy.

\section{Bar Graph of Nodes}

Bar graph shows the maximum and minimum count of the factors used by the respondent. Tallest plot shows the maximum repetition while shortest plot shows the minimum repetition of word. 


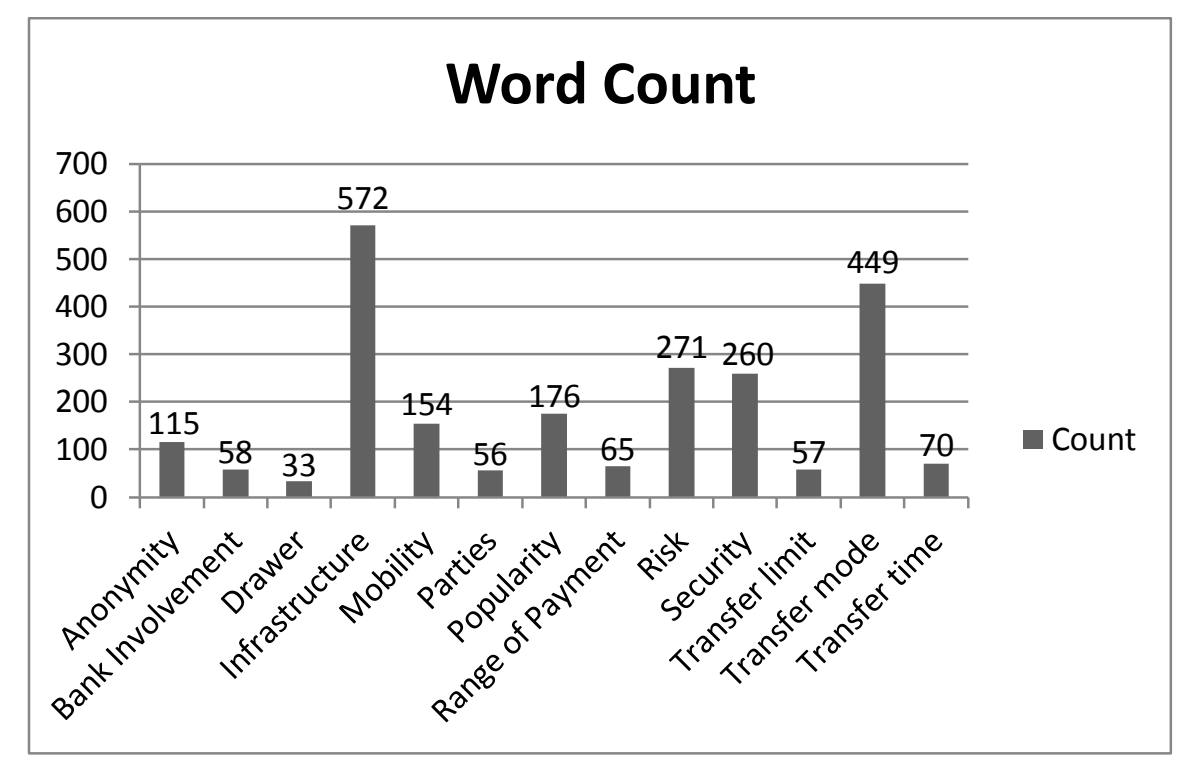

Fig. 1. Bar Graph of Nodes

From figure 1 it can be said that Infrastructure, transaction mode and risk are having higher range of codes and on other side Drawer, Parties and Range of Payment having less higher range of codes in the chart.

\section{$4 \quad$ RESULT AND DISCUSSION}

With the help of number and frequency table and Bar Graph of Nodes, it is observed that Infrastructure [34], Security [3][7-8][16][18][22-24][29][3133][35][38] and Risk are the major factors of adoption of digital payment in Allahabad city. Subsequently, Awareness [40], Habit of use cash [12], ease of use [5][17][36-37], cost effective [4][39] are another factors, to implement the digital payment system in India. Without sufficient infrastructure, risk management and security solutions of digital payment, system could not be achieved the goal of study. Cashless system is not only requirement but also a need of the society [38]. The transformation from a cash-centric economy to electronic one would need more time and awareness; people should trust and have faith on the cashless system with [8]; ease to use [5][17][36-37], minimal charges [4][39], high level of security [18], and accessible to all [24]. Apart from the selected 13 factors, there are few more factors that respondent discussed like, government policies, market, type of card, type of mobile 
device, need and usage of e-payment system etc., but these factor were not included in the study because they were not important or marginally important than the others. There are multiple digital payment systems exist in the Indian market like, NEFT/RTGS, IMPS, Plastic money, Mobile banking, UPI, AEPS, BHIM, USSD, m-wallets [28]. In order to increase the penetration and popularity of an electronic payment system, government as well as nongovernment organisations need to alliances with other industries such as telecommunications, television, advertising agencies, financial and retail firm will be needed with regular awareness and synergy specially in rural and semi-urban areas. For internet connectivity government need to establish tower or internet connections in rural and semi-urban area of the country. Government provide awareness also, among the users through advertisement and awareness program.

\section{LIMITATION AND CONCLUSION}

The study indentified 13 factors namely: Anonymity, Bank Involvement, Drawer, Infrastructure, Mobility, Parties, Popularity, Range of Payment, Risk, Security, Transfer limit, Transfer mode, and Transfer time for successful implementation of digital payment system at Allahabad city. It is also evident that the replication of digital payment system at other cities are possible after resolving few issues like, infrastructure, awareness, management of risk and security issues. There are some limitations with the study that, this is a city based analyses which is limited to Allahabad city only. Result may differ if large geographical area has been taken as sample area. Subsequently, the longitudinal study in terms of time as well as money may differ the result.

\section{References}

1. Achor PN, Robert A (2013) Shifting Policy Paradigm from Cash-Based Economy to Cashless Economy: The Nigeria Experience, Afro Asian Journal of Social Sciences, vol 4(4).

2. Andrade AD (2009) Interpretive Research Aiming at Tehory Building: Adopting and Adapting athe case study Design. The Qualitative Report, vol 14(1), pp 42-60. Retrieved from http://nsuworks.nova.edu/tqr/vol14/iss1/3/

3. Chellappa R, Pavlou P (2002) Perceived information security, nancial liability and consumer trust in electronic commerce transactions. Logistics Information Management, vol 15(5), pp 358-368. 
4. Das A, Agarwal R (2010) Cashless Payment System in India- A Roadmap, Technical Report, Indian Institute of Technology Bombay, Department of Mathematics, Bombay.

5. Davis FD (1989) Perceived usefulness, perceived ease of use, and user acceptance of information technology, MIS Quarterly, vol 13(3), pp 319-340.

6. Eastin MJ (2002) Diffusion of e-commerce: an analysis of the adoption of four ecommerce activities, Telematics and Informatics, vol 19(3), pp 251-267.

7. Fatimah MA, Kusairi MN, Mohd FA (2000) E-commerce adoption in Malaysia: Problems and Barriers from the firms' perspective, Proceedings of International Conference on Electronic Commerce.

8. Friedman B, Kahn PH, Howe DC (2000) Trust online, Communications of the ACM, vol 43(12), pp 34-40.

9. Gans JS, Scheelings R (1999) Economic Issues Associated with Access to Electronic Payment Systems.

10. Ghauri P (2004) Designing and conducting case studies in international business research. Handbool of qualitative research methods for international business, pp 109-124.

11. Group, HDFC Bank Investment Advisory (2016) Demonetization and Its Impact, Event Update, Retrieved on 11 November, 2016 from https://www.hdfcbank.com/assets/pdf/Event_Update_Demonetization_and_its_impact.pdf.

12. Hataiseree R (2008) Development of e-Payments and Challenges for Centreal Banks: Thailand's Recent Experience, Working Paper , pp 1-53.

13. Hirschman E C (1982) Consumer payment systems: the relationship of attribute structure to preference and usage, Journal of Business, vol 55(4), pp 531-545.

14. Hord J (2005) How Electronic Payment Works.

15. INSIGHTS (2016) The Big Picture- Impact of Demonetization, InsightsIAS. Retrieved on 11 November, 2016 from http://www.insightsonindia.com/2016/11/16/big-picture-impactdemonetization/

16. Kousaridas A, Parissis G, Apostolopoulos T (2008) An Open Nancial Services Architecture based on the use of Intelligent Mobile Devices, Electronic Comerce Research and Applications, vol 7(2), pp 232-246.

17. Legris $P$, Ingham J, Collerette $P$ (2003) Why do people use information technology? A critical review of the technology acceptance model, Information and Management, vol 40(3), pp 191-204.

18. Linck K, Pausttchi K, Wiedemann DG (2006) Security issues in mobile payment from the customer viewpoint, Proceedings of the 14th European Conference on Information System (ECIS 2006), pp 1-11

19. Livemint (2016) Making India a cashless economy, Retrieved on 02 April, 2017 from http://www.livemint.com/Opinion/XGbavEnoeP7dZITeh21MRM/Making-India-acashless-economy.html 
20. Malaysia CB (2009) Payment and Settlement Systems Report.

21. Marco A, Bandiera L (2004) Monetary Policy, Monetary Areas and Financial Development with Electronic Money, IMF Working Study, IMF.

22. Md Johar MG, Ahmad AJ (2011) The Role of Technology Acceptance Model in Explaining Effect on e-Commerce Application System, International Journal of Managing Information Technology, vol 3(3), pp 1-14.

23. Oh S, Kurnia S, Johnston RB, Lee H, Lim B (2006) A Stakeholder Perspective on Successful Electronic Payment Systems Diffusion. Proceeding of the Hawaii International Conference on Systems Sciences (HICSS-39), Hawaii.

24. Poon WC (2008) Users' Adoption of e-Banking Services: The Malaysian Perspective. Jaournal of Business and Industrial Marketing , vol 23(1), pp 59-69.

25. Shah Alpesh et. at. (2016) Digital Payments 2020: The Making of a $\$ 500$ Billion Ecosystem in India, The Boston Consulting Group.

26. Shon TH, Swatman PM (1998) Identifying Effectiveness Criteria for Internet Payment System. Internet Research: Electronic Networking Applications and Policy, vol 8(3), pp 202-218.

27. Siccama CJ, Penna S (2008) Enhancing validity of a qualitative dissertation research study by using NVivo, Qualitative research journal, vol 8(2), pp 91-103.

28. Singh S (2017) The Economic Times, Why Mobile Wallets will Die Lucknow, p 14.

29. Singh S (1998) Helping Consumers Realise the Potential of the e-Commerce Revolution. Centre for International Research on Communication and Information Technologies .

30. Siu NYM, Mou JCW (2005) Measuring service quality in internet banking: the case of Hong Kong, Journal of International Consumer Marketing, vol 17(4), pp 99-116.

31. Streeter W (1997) Could e-Cash Threaten Pyament Integrity? American Bankers Assocuation (ABA) Journal , vol 89(11), pp 58-68.

32. Stroborn K, Heitmann A, Leibold K, Frank G (2004) Internet Payments in Germany: A Classificatory Framework and Empirical Evidence. Journal of Business Research, vol 57(12), pp 1431-1437.

33. Sumanjeet S (2009) Emergence of Payment System in the Age of Electronic Commerce: The State of Art.

34. Tim Jones (1999) The future of digital money, European Business Review, vol 99(4), pp 261-264.

35. Tsiakis T, Sthephanides G (2005) The concept of Security and Trust in Electronic Payments. Computers and Security, vol 24(1), pp 10-15.

36. Venkatesh V, Davis FD (2000) A theoretical extension of the technology acceptance model: four longitudinal field studies, Management Science, vol 46(2), pp 186-204. 
37. Wang WT, Li HM (2011) Factors influencing mobile services adoption: a brand-equity perspective. Internet Research , vol 22(2), pp 142-179.

38. Wang YS, Wang YM, Lin HH, Tang TI (2003) Determinants of User Acceptance of Internet Banking: An Empirical Study, International Journal of Service Industry Management, vol 14(5), pp 501-519.

39. Williamson Stephen (1986) Costly Monitoring, Financial Intermediation and Equilibrium Credit Rationing, Journal of Monetary Economics, vol 18 (2), pp 159-79.

40. Worku G (2010) Electronic-Banking in Ethiopia- Practices, Opportunities and Challenges, Journal of Internet Banking and Commerce, vol 15(2).

\section{Websites}

41. http://cashlessindia.gov.in/

42. http://census2011.co.in/

43. https://www.rbi.org.in/

44. http://www.npci.org.in/ 